http://ejournal.upi.edu/index.php/jaz - e-mail: jurnal.zonasi@gmail.com dan jurnal_zonasi@upi.edu doi.org/10.17509/jaz.v3i1.17470

\title{
OPTIMALISASI DESAIN FASAD BANGUNAN RESTAURANT DI KEBONWARU, BATUNUNGGAL KOTA BANDUNG
}

\author{
Article History: \\ First draft received: \\ 28 Mei 2019 \\ Revised: \\ 8 Juni 2019 \\ Accepted: \\ 10 Junir 2019 \\ Final proof received: \\ Print: \\ 14 Juni 2019 \\ Online \\ 17 Juni 2019
}

\author{
Hafiz Nurahman ${ }^{1}$; Ridwan Muslim ${ }^{2}$ \\ 1,2 Program Studi S1 Arsitektur, FPTK, Universitas Pendidikan Indonesia \\ Email: hafiznurahman15@gmail.com
}

Abstract: Bandung is a country with a tropical climate. The highest temperature reaches $32^{\circ} \mathrm{C}$ while the highest solar radiation exposure is more than 10 hours. On the other hand, the top speed of the wind only reaches $1 \mathrm{~m} / \mathrm{s}$. As a tourist city, building design in Bandung is demanded to be able to offer convenience for tourist visitors. Located at an altitude of 600-900dpl, the city of Bandung in addition to having an average air of $28^{\circ} \mathrm{C}$, an average humidity of 68, thus significantly influencing the achievement of thermal comfort in the building to be designed. This paper aims to analyze the facade design of recreational-culinary function buildings that are able to respond to the tropical climate, especially those that offer thermal comfort to visitors. The double skin hollow facade system and there are hinges that are able to respond to interactions between buildings, wind, and sun exposure, so that wind speed and sun exposure can be optimally regulated through the dynamic function of the building's façade. Design experiments using the sunhour and flow design plugins to assess solar radiation and wind speed by manipulating facades, especially in the northern orientation can reduce sun exposure in 5-7 hours.

Keywords: Building facade design, tropical building design, thermal comfort.

\begin{abstract}
Abstrak: Bandung merupakan negara dengan iklim tropis. Suhu tertinggi mencapai $32{ }^{\circ} \mathrm{C}$ sementara paparan radiasi matahari tertinggi lebih dari $10 \mathrm{jam}$. Di sisi lain, kecepatan tertinggi angin hanya mencapai $1 \mathrm{~m} / \mathrm{s}$. Sebagai kota wisata, desain bangunan di Bandung dituntut mampu menawarkan kenyamanan bagi para pengunjung wisata. Terletak pada ketinggian 600-900dpl, Kota Bandung selain memiliki udara rata-rata $28^{\circ} \mathrm{C}$, kelembapan rata-rata 68 , sehingga berpengaruh secara signifikan terhadap pencapaian kenyamanan termal pada bangunan yang akan didesain. Tulisan ini bertujuan untuk menganalisis desain fasade pada bangunan fungsi rekreatif-kuliner yang mampu merespon iklim tropis, terutama yang menawarkan kenyamanan termal pengunjungnya. Sistem double skin fasade berongga dan terdapat engsel yang mampu merespon interaksi antara bangunan, angin, dan paparan sinar matahari, sehingga kecepatan angin dan paparan sinar matahari dapat diatur secara optimal melalui fungsi dinamis façade bangunan. Percobaan desain menggunakan plugin sunhour dan flow desain untuk menilai radiasi matahari dan kecepatan angin dengan memanipulasi fasade, terutama di orientasi utara mampu mengurangi paparan matahari dalam 5-7 jam.
\end{abstract}

Kata Kunci: Desain fasade bangunan, desain bangunan tropis, kenyamanan termal.

\section{Pendahuluan}

Bandung merupakan salah satu kota tujuan wisata terpopuler di Indonesia (Permana dan Wijaya, 2013), terutama tujuan alam dan kulinernya (Permana dan Wijaya, 2017; Anjani, 2017). Restoran merupakan sarana 
komersial yang dijadikan sebagai objek kunjungan publik untuk memenuhi kebutuhan kuliner. Setiap restoran yang terbangun biasanya memiliki ciri khas tersendiri yang menjadi daya tarik pengunjungnya. Tingkat kepuasan konsumen terhadap produk dan pelayanan ditinjau dari reliability, responsiveness, assurance, empathy berada pada kategori execellent, sedangkan ditinjau dari tangibles berada pada kategori puas (Charles R. Ngangi, MS., and Ir. Eyverson Ruauw 2014.). Sebuah proyek bangunan harus dapat memenuhi batas penggunaan energi tahunan secara maksimum agar tercapai standar sebuah bangunan yang paling tidak mencapai $60 \%$ hemat energi secara keseluruhan. Desain bangunan pasif menjadi suatu solusi pemenuhan kebutuhan energy dengan pertimbangan penempatan orientasi rumah dan penempatan bukaan yang dimanfaatkan semaksimal mungkin untuk mendapatkan energy alami dan meminimalisir penggunaan energy buatan. Bangunan Pasif dirancang dengan bentuk bangunan masif, dan sebagian besar desain mereka pada dasarnya berbentuk kotak. Hal ini dimaksudkan untuk mengikuti teknik-teknik bangunan pasif, yaitu mengurangi luas permukaannya, dengan jendela-jendela utama berorientasi pada jalur matahari untuk memanfaatkan panas matahari semaksimal mungkin. Pada lingkungan tropis, strategi desain bangunan pasif yaitu dengan mempertimbangkan kontrol pada suhu ekstrim, pencahayaan dan peralatan listrik, ventilasi mekanis, konstruksi kedap udara, juga uji kebocoran yang merupakan beberapa syarat uji sertifikasi.
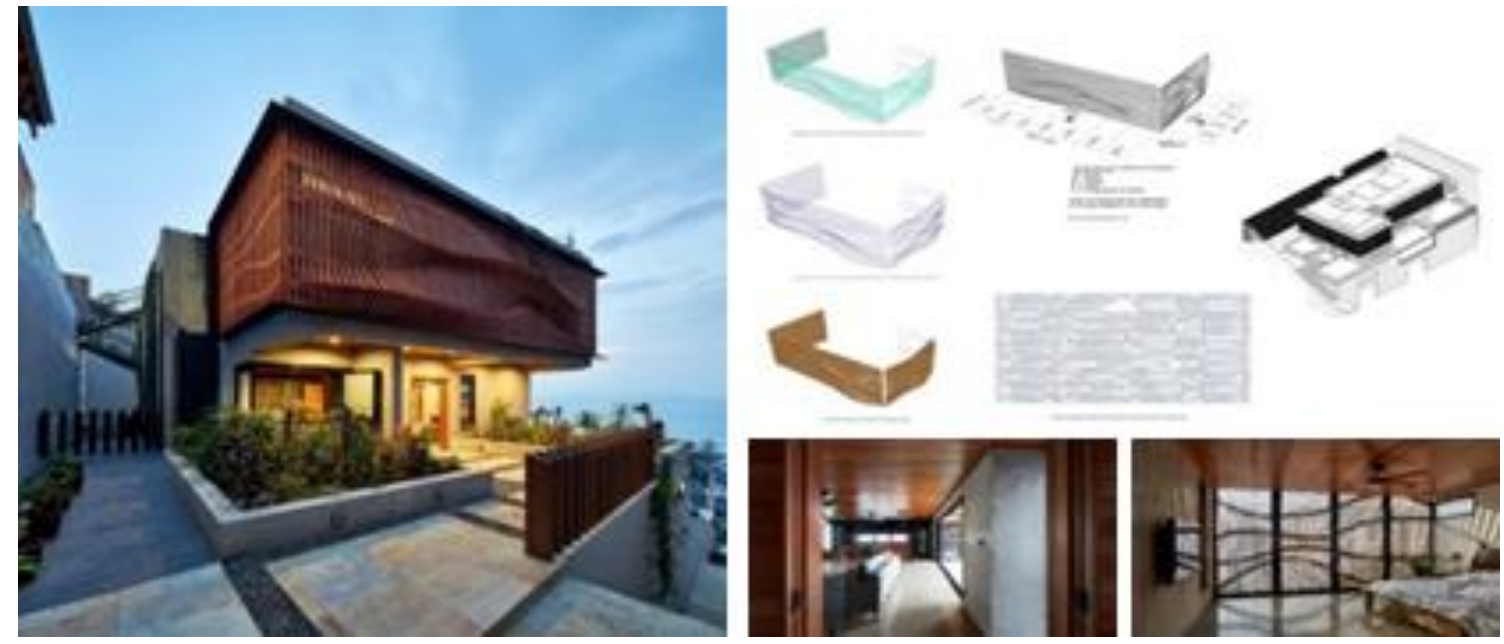

Gambar 1. Aestetic Façade and atmosphere Interior comfort from Brise Soleil House, Studio Workshop

\section{Sumber: www.Arch2O.com}

Fasade merupakan elemen arsitektural utama dari segi visual dan sangat penting karena .. merupakan bagian yang selalu pertama kali diapresiasi oleh publik (penikmat karya arsitektur) (Bangunan, Ruang, \& Arsitetkur, 2013). Di samping berfungsi sebagai citra visual, fasade merupakan "kulit" terluar yang berhubungan secara langung dengan ruang luar, sehingga berkontribusi secara langsung terhadap heat transfer radiasi luar ke dalam ruangan dengan melakukan metode double skin (selubung ganda) yang mampu mencapai kenyamanan termal.

Brise Soleil House, salah satu desain di Port Moresby, Papua New Guinea yang menerapkan beton cast-in-site sebagai komponen utama bangunan yang sebagian sisi terbukanya ditutupi fasade kayu bergelombang yang memberikan naungan, privasi, dan ventilasi ke kamar utama.(Ahmed, 2018a).

Ini bisa dilihat keberhasilannya dalam fasadenya yang mampu menjadi layar penuh fentilasi yang dapat dioperasikan untuk mengontrol matahari barat seperti terlihat pada gambar 1. Konsep double skin façade juga diterapkan pada Restauran Bossa di São Paulo, Brazil. Restoran ini menggunakan fasade selubung ganda, yaitu suatu sistem konstruksi fasade bangunan yang terdiri atas dua selubung (selubung luar dan selubung dalam) pada penerapannya (Ahmed, 2018b). Diantara kedua selubung tersebut terdapat rongga yang berisi udara dan dapat ditambahkan elemen peneduh berupa horizontal - blind. Di bagian atas dan bawah dari konstruksi fasade selubung ganda tersebut terdapat bukaan ( in - let and out - let ) sebagai wadah pertukaran udara dari luar ke dalam selubung dan dari dalam ke luar selubung. Sistem selubung ganda ini bisa dilihat pada Gambar 2. 


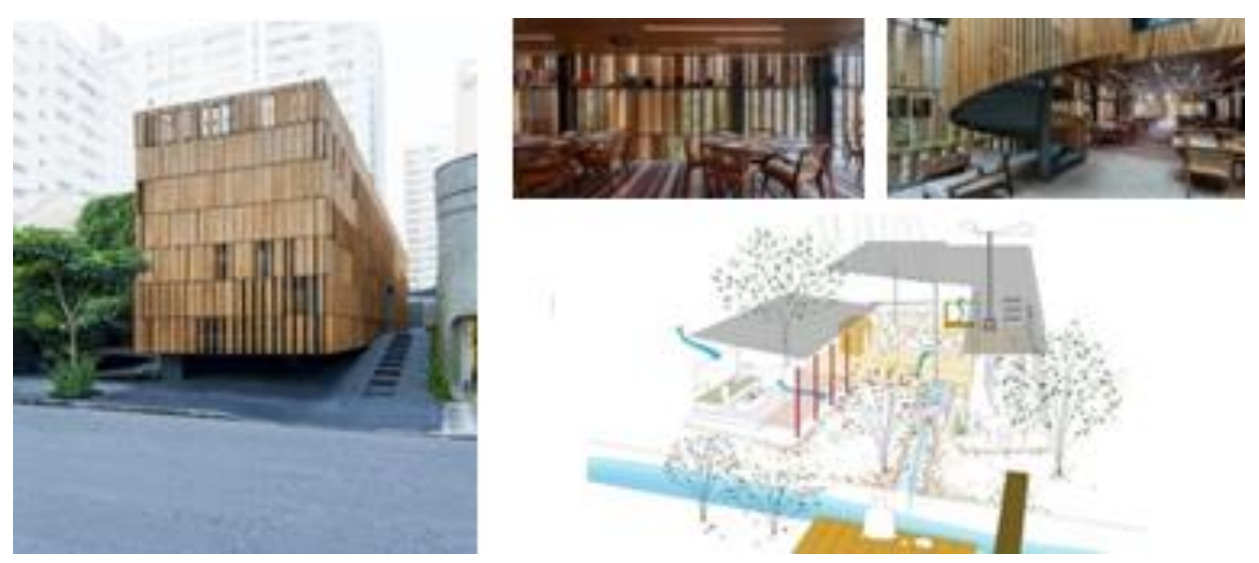

Gambar 2. Review Space Condition andAir Flow Concept by Double Skin Façade from Restaurant Bossa Sumber: www.Arch2O.com

Dengan konstruksi selubung seperti ini, akan terjadi proses pertukaran udara di dalam selubung yang akan mengalirkan panas dari dalam selubung sehingga menyebabkan beban panas permukaan selubung bagian dalam akan berkurang (Mulyadi, 2016).

Desain perancangan bangunan rekreatif-kuliner pada artikel ini kemudian akan mengeksplorasi konsep double skin façade. Fasade ini direncanakan dapat mengoptimalkan suhu ruangan dan memperhatikan visual bangunan.

a. Desain pasif untuk kenyamanan termal Standar EFA (exploratory factor analysis)

EFA mengindikasikan bahwa nostalgia konsumen dipicu oleh empat faktor, yaitu: makanan, event, lingkungan, dan karyawan (M. S. Rahma and P. Wardono et al. 2017). Berkaitan dengan lingkungan, suhu udara yang nyaman bagi aktivitas manusia adalah $21-250 \mathrm{C}$ dan kelembapan udara sekitar 50\% (S. Hestiningrum 2014). Menurut Brady dan Cronin pelanggan mengevaluasi kualitas layanan didasarkan pada tiga kualitas yaitu kualitas interaksi, kualitas lingkungan fisik, dan kualitas hasil. Gronroos (2000) juga menyebutkan bahwa "pada dasarnya kualitas layanan yang dievaluasi oleh pelanggan memiliki dua dimensi, yaitu a technical quality atau outcome quality dan a functional quality atau interaction quality". Lalu Rust dan Oliver (Gronroos, 2000) menambahkan physical environment sebagai dimensi lain yang akan dievaluasi oleh pelanggan terhadap kualitas layanan. Atribut-atribut yang ada dalam SERVQUAL sangat penting dalam pembentukan perceived service quality ini. (S. Hestiningrum 2014)

b. Standar kenyamanan termal

Metode penilaian kenyamanan termal yang digunakan adalah menggunakan dasar studi yang dilakukan oleh Fanger (1970). Studi yang dilakukan oleh Fanger ini adalah mengkombinasikan antara Standar Kenyamanan Termal Norma Internasional dengan ASHRAE Handbooks- Fundamental. Hasil kombinasi ini didasarkan pada perhitungan antara parameter pribadi yaitu seberapa berat aktivitas dan insulasi pakaian dan parameter lingkungan yaitu kecepatan udara, suhu, dan kelembaban (Fanger and J. Toftum 2002). CBE Thermal comfort tool

CBE Thermal comfort tool ini digunakan untuk mengetahui indeks kenyamanan yang kemudian dipresentasikan dalam tabel kenyamanan termal (S. Hirabayashi and F. Imamura et al. 2018).

\section{c. Plug-in Sun-Hour}

Sunhour merupakan plug-in yang terpasang pada aplikasi Google Sketchup. Plug-in ini memiliki berbagai macam fungsi sebagai berikut.

- Mengetahui seberapa lama fasade bangunan terpapar sinar matahari;

- Representasi grafis tentang lama penyinaran matahari melalui grid;

- Mengetahui bagaimana skema penyinaran pada fasade yang akan berpengaruh pada lamanya sinar matahari yang terpapar pada fasade;

- Mengatur tes penyinaran matahari berdasarkan lokasi dan waktu yang akurat;

- Mengetahui hasil terbaru dari perubahan desain yang dilakukan. 


\section{d. Autodesk Flow Design 2014}

Autodesk Flow Design merupakan aplikasi simulasi untuk mengetahui aliran angin di sekitar benda yang akan dianalisis. Fitur ini juga dapat mensimulasikan aliran angin setelah dilakukan perubahan desain pada objek tersebut. Aplikasi ini dapat menunjukkan berapa kecepatan angin sesuai dengan kondisi lingkungan yang akan disimulasikan.

\section{Lokasi dan Data Perancangan}

\section{a. Lokasi}

Objek restoran yang digunakan berlokasi di Jl. Jakarta, Kebonwaru, Batununggal, Kota Bandung. Lokasi geografis kawasan ini adalah $6^{\circ} 51^{\prime} 52,5$ "S dan $107^{\circ} 35^{\prime} \mathrm{A} 34,5^{\prime}$ E. Total luas lahan sekitar 169,468 m2 dan restoran $1720 \mathrm{~m} 2$ (gambar 3 ).

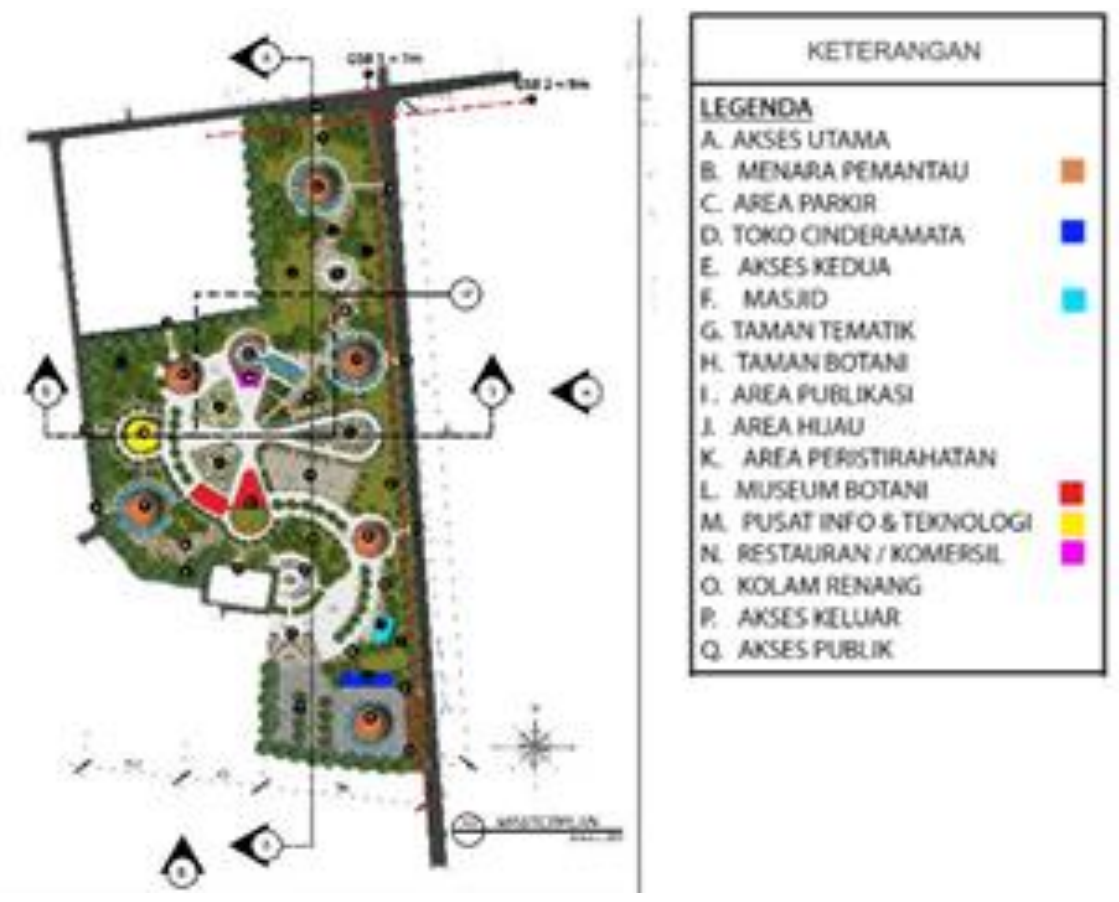

Gambar 3. Masterplan Taman Hutan Kota

Sumber: dokumentasi penulis

b. Iklim

Data eksisting diambil dari Meteoblue Bandung sebagai berikut :

b. 1. Suhu Rata-rata dan Presipitasi

Di kota Bandung, bulan Agustus 2018 memiliki suhu rata-rata paling tinggi yaitu 28oC dan terendah pada bulan July yaitu 19oC. (Meteoblue, 2018). Suhu yang terdapat pada data meteoblue ini selanjutnya digunakan sebagai initial data untuk dasar merancang serta perhitungan kenyamanan termal.

\section{Hasil dan Pembahasan}

\section{a. Bentuk Masa Bangunan}

Konsep bentuk restoran ini diambil dari metafora tumbuhan air bernama apu-apu (water cabbage). Tanaman air ini memiliki ukuran daun berbeda dengan pembentukan variasi ruang di bagian bawah. Digunakan metode adisi pada bentukan asli, dengan mengurangi bagian tengah tanaman menjadi area terbuka bagi bangunan. 


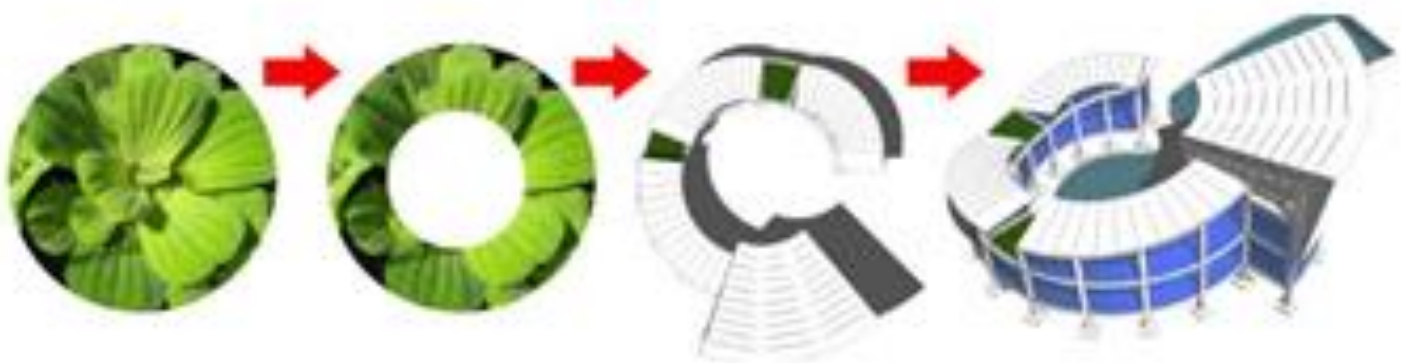

Gambar 4. Konsep gubahan masa bangunan restoran Sumber: dokumentasi penulis

Konsep desain fasade pada restoran ini mengacu pada pengaruh radiasi matahari dan angin terhadap kondisi kenyamanan termal bangunan (Gambar 5). Fasade yang dapat digerakan dengan sistem engsel ini dapat mudah diatur berdasarkan kondisi iklim di lingkungan sekitarnya.

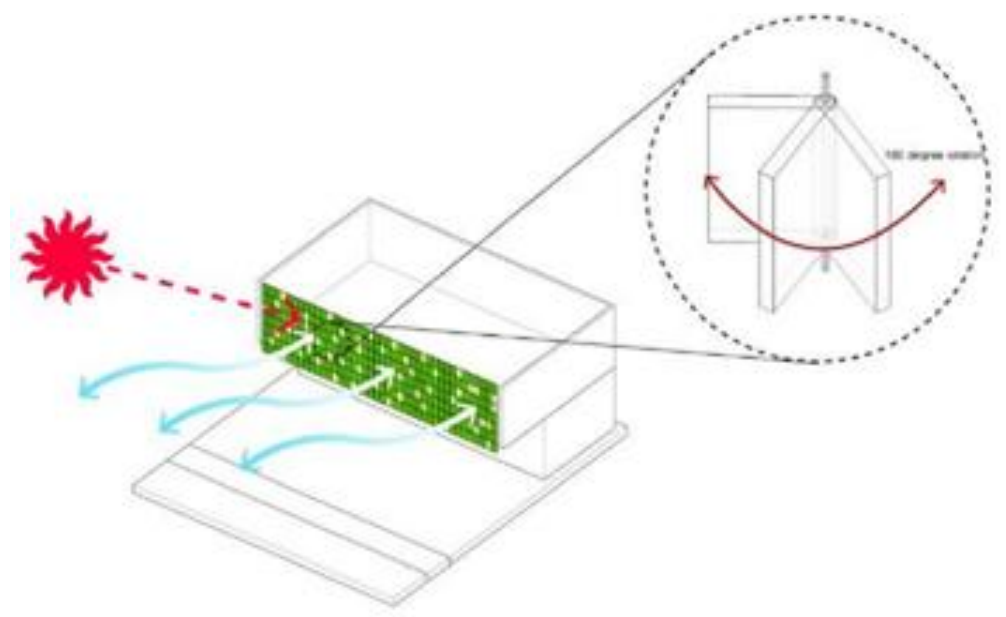

Movicks treade for lighe wind and shodow

Gambar 5. Movable facade cheongcheon restaurant Sumber: https://www.dezeen.com

Orientasi Bangunan

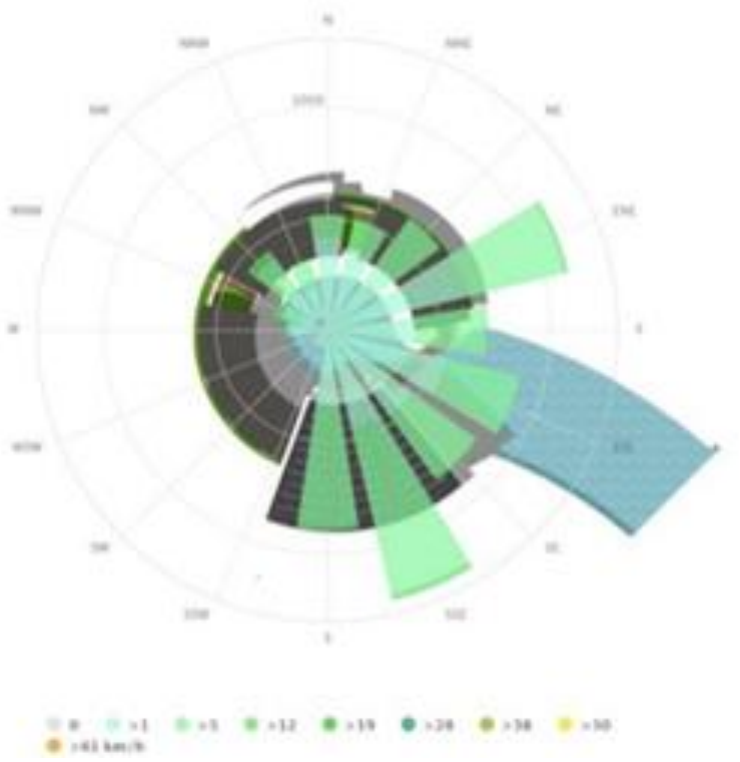

Gambar 6. Orientasi Bangunan Meteoblue Bandung Sumber: Meteoblue Bandung 
Angin pada arah selatan tenggara memiliki kecepatan $3 \mathrm{~m} / \mathrm{s}$. Digunakanlah double skin facades pada bagian bangunan yang mengarah langsung ke selatan tenggara (Gambar 6). Penghawaan alami lebih diutamakan dibandingkan dengan penghawaan buatan (Green Building Council Indonesia) sehingga angin lokal yang mengalir di sekitar bangunan harus dimanfaatkan (R. Kriteria and D. R. Development et al. 2012). Kemudian dilakukan simulasi seberapa optimal kondisi termal bangunan restoran yang direncanakan menggunakan beberapa simulasi yang berpengaruh pada tingkat kenyamanan penggunanya

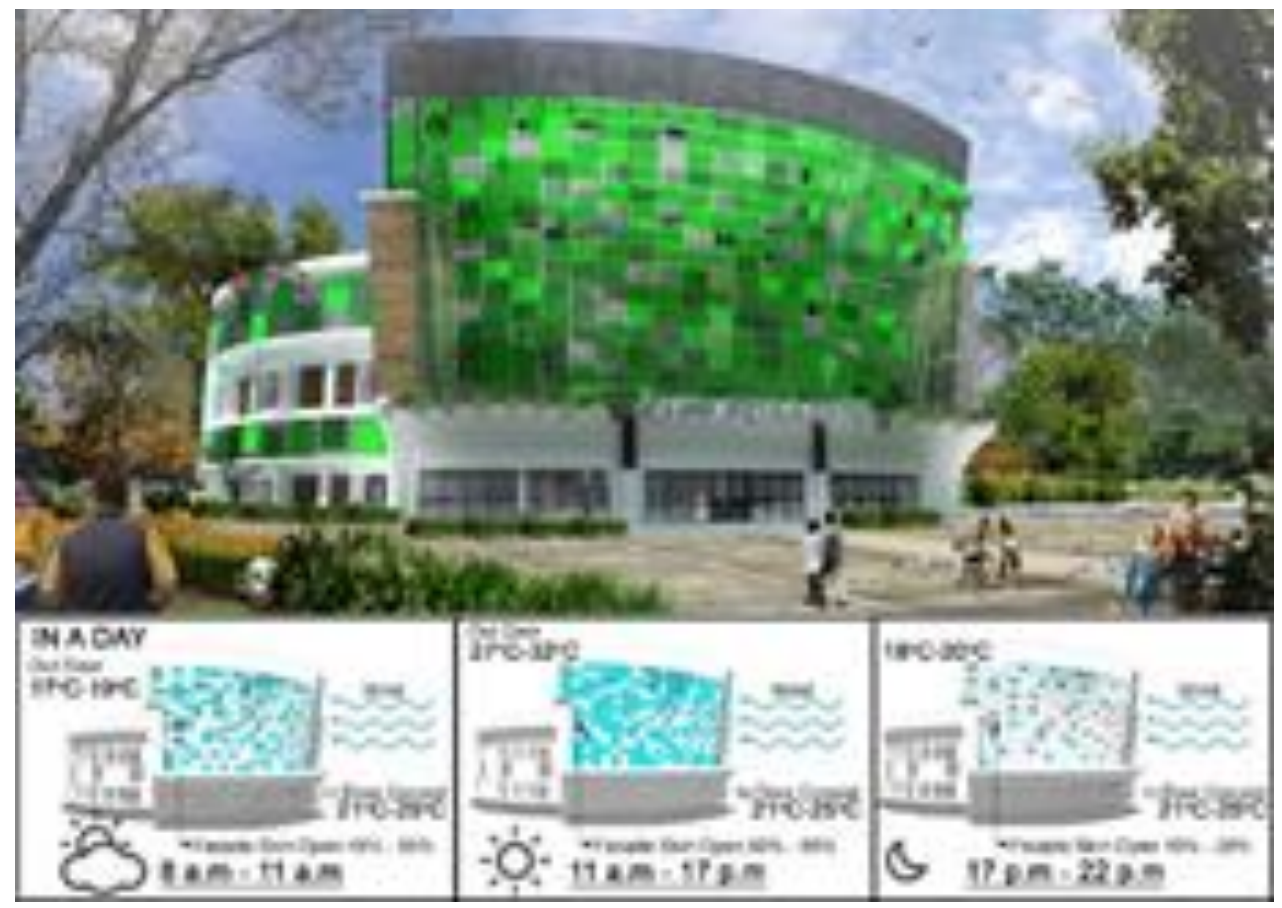

Gambar 7. Double Skin System Concept

Sumber: Dokumentasi Penulis

Restoran yang dirancang menggunakan konsep fasade double skin, yang dapat mengoptimalkan suhu ruangan dan visual eksterior seperti pada gambar 7.

\section{b. Sun-Hour Sketch-Up Plugin}

Simulasi ini digunakan untuk mengetahui paparan radiasi matahari pada bangunan restoran. Simulasi ini digunakan untuk menganalisis fasade bangunan di keempat sisinya, yaitu (1) bagian selatan-barat, (2) bagian barat-utara, (3) bagian utara-timur, dan (4) bagian timur-selatan.

Pada fasade bagian selatan- barat terpapar radiasi matahari sebesar 20\% (2-5 jam) ditandai dengan dominasi grafis warna biru (Gambar. 8A).
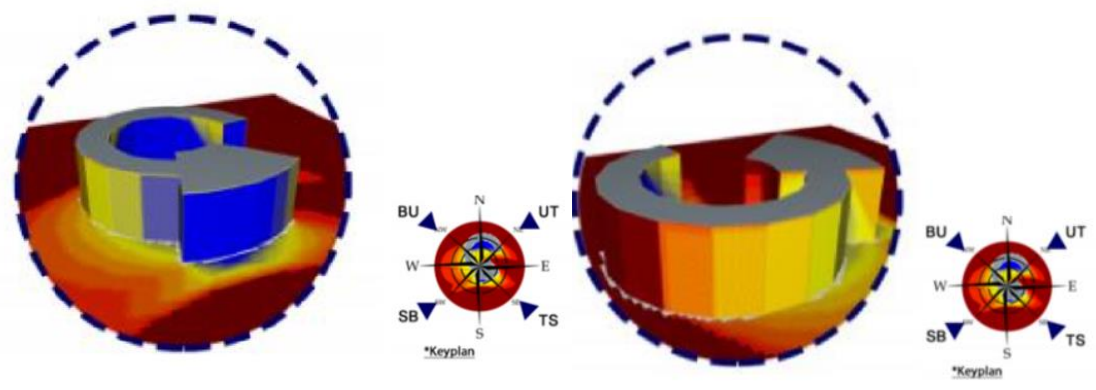

Gambar 8. Hasil simulasi sunhour (A) bagian Selatan Barat \& (B) bagian Barat Utara Sumber: dokumentasi penulis

Pada fasade bagian barat- utara terpapar radiasi matahari sebesar 80\% (5-9 jam) ditandai dengan dominasi grafis warna jingga-merah (Gambar 8B).

Pada fasade bagian utara- timur terpapar radiasi matahari sebesar 100\% (9-12 jam) ditandai dengan dominasi grafis warna merah (Gambar 9A). 

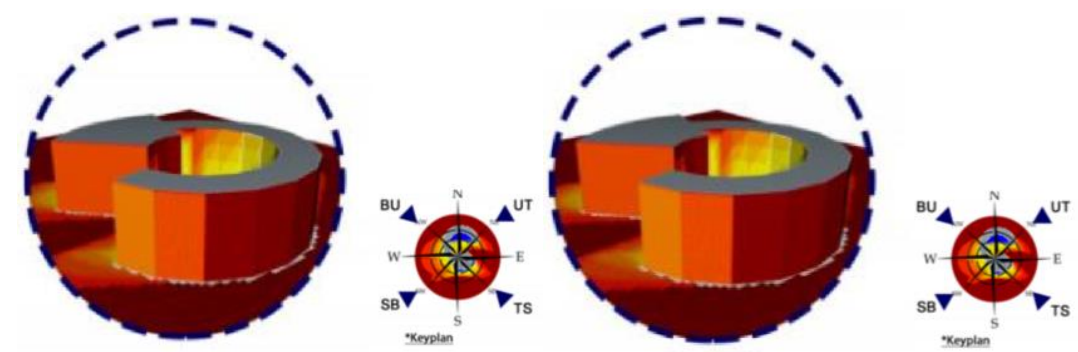

Gambar 9. Hasil simulasi sunhour (A) bagian Utara Timur \& (B) bagian Timur Selatan Sumber: dokumentasi penulis

Pada fasade bagian timur- selatan terpapar radiasi matahari sebesar 60\% (2-7 jam) ditandai dengan dominasi grafis warna kuning (gambar 9B).

Bagian dari masa bangunan yang terpapar radiasi matahari paling tinggi dan memerlukan penanganan yaitu pada bagian utara-timur dan timur-selatan. maka dilakukan solusi sebagai berikut :
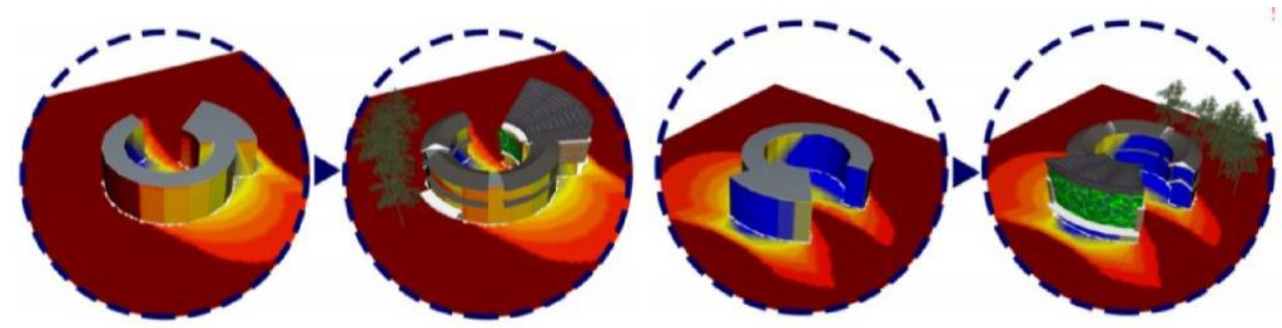

Gambar 10. (A)Kanopi (teritisan) sebagai solusi radiasi matahari berlebih, (B) Movable fcades sebagai solusi turbulensi

Sumber: dokumentasi penulis

- Pada bagian utara pada perencanaan digunakan sistem kanopi dengan memasang teritisan atap pada sisi bangunan, pemasangan kanopi tersebut mampu mereduksi radiasi matahari menjadi 20\% (3-5 jam). (Gambar 10A)

- Pada bagian timur tenggara yang cenderung terpapar radiasi matahari normal, namun teraliri angin paling tinggi sehingga digunakan sistem movable facades yang dapat mengatasi turbulensi di dalam ruangan utama bangunan (Gambar 10B).

\section{c. Autodesk Flow-Design 2014}

Sesuai dengan hasil perhitungan menggunakan software CBE, angin yang harus masuk ke dalam restoran adalah $3 \mathrm{~m} / \mathrm{s}$, maka pengunjung restoran akan merasakan kenyamanan $24.9^{\circ} \mathrm{C}$ dengan $28.2^{\circ} \mathrm{C}$. Karena angin yang dibutuhkan sebesar $3 \mathrm{~m} / \mathrm{s}$ udara pada ruangan restoran mampu terkondisikan sesuai suhu yang optimal (PET 29ㄷ). (Gambar 11)

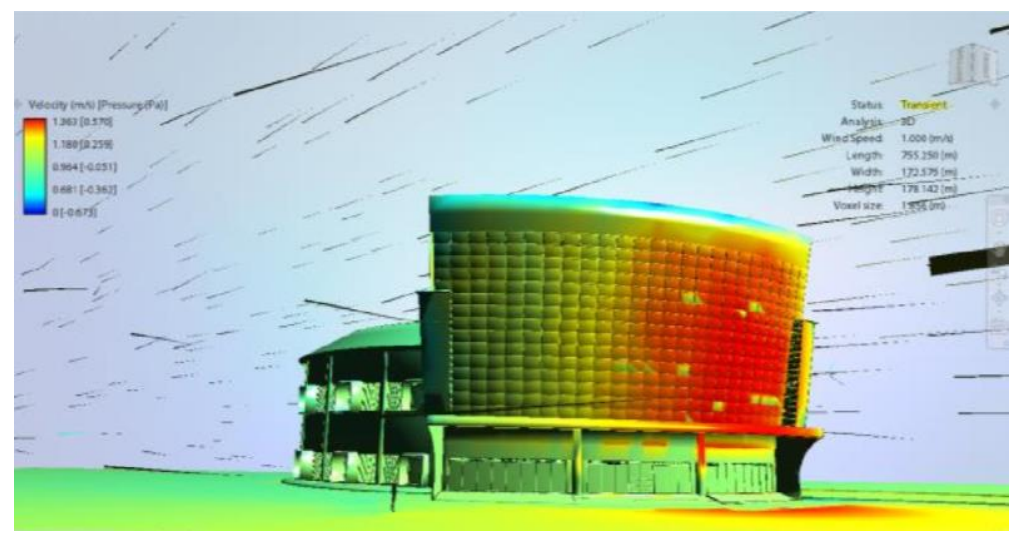

Fig. 11. Simulasi Autodesk flow-design 2014 Sumber: dokumentasi penulis 
c. 1. $\quad$ CBE Thermal Comfort Tool

CBE Thermal comfort tool ini digunakan untuk mengetahui indeks kenyamanan yang kemudian dipresentasikan dalam tabel kenyamanan termal. Maka didapat grafik kenyamanan termal dengan detail sebagai berikut (Fig. 12)
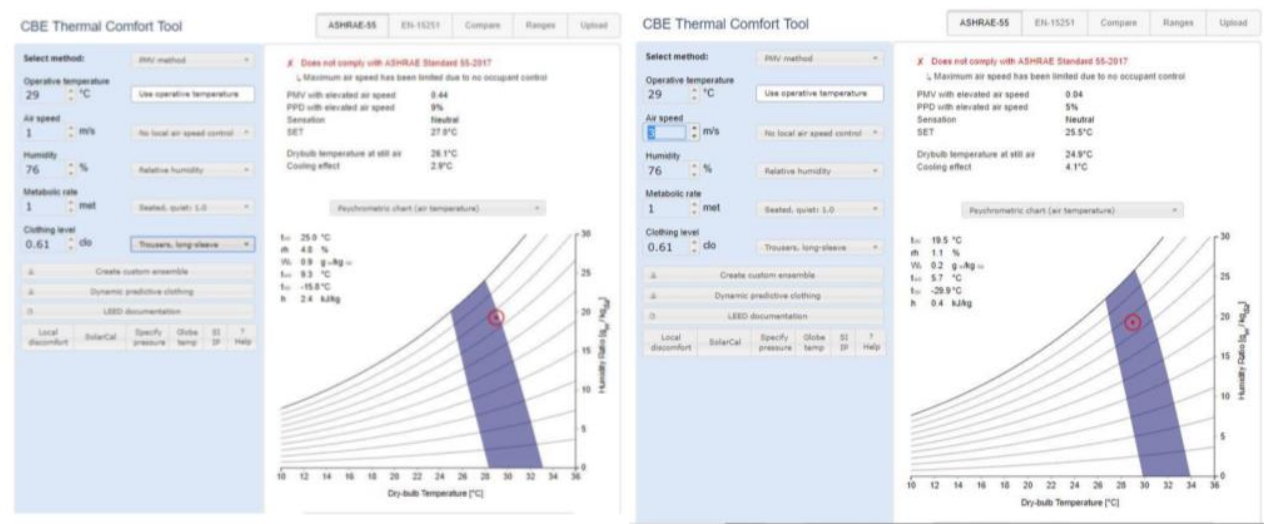

Fig. 12. Grafik CBE (A) dengan angin $1 \mathrm{~m} / \mathrm{s}$ (B) dengan angin $3 \mathrm{~m} / \mathrm{s}$ Sumber: dokumentasi penulis

\section{Kesimpulan dan Rekomendasi}

\section{Kesimpulan}

Rekayasa fasad bangunan dengan pendekatan arsitektur kontemporer tropis ini terbukti mampu menghadirkan kecepatan angin outdoor tertinggi $1 \mathrm{~m} / \mathrm{s}$ dan $3 \mathrm{~m} / \mathrm{s}$, menjadi $0.2 \mathrm{~m} / \mathrm{s}$ hingga $0.3 \mathrm{~m} / \mathrm{s}$ dalam ruang indoor sehingga mampu mencapai kenyamanan termal indoor mencapai suhu rata-rata $21^{\circ} \mathrm{C}$ hingga $25^{\circ} \mathrm{C}$. Hasil perhitungan berdasarkan dua kondisi angin berbeda tersebut menyatakan kenyamanan termal telah tercapai dengan standar kenyamanan antara $21^{\circ} \mathrm{C}$ hingga $25^{\circ} \mathrm{C}$. Ketercapaian simulasi ini didapat PET dengan kecepatan angin $1 \mathrm{~m} / \mathrm{s}$ yang dihasilkan adalah $30.8^{\circ} \mathrm{C}$ PET atau setara dengan $25^{\circ} \mathrm{C}$ suhu sebenarnya, sedangkan pada PET dengan kecepatan angin $3 \mathrm{~m} / \mathrm{s}$ yang dihasilkan adalah $28.2^{\circ} \mathrm{C}$ PET atau setara dengan $22.8^{\circ} \mathrm{C}$ suhu sebenarnya. Maka penggunaan software sangat menentukan suatu desain yang optimal melalui metode trial and error sebelum terlaksananya pembangunan di kawasan tropis atau dengan kondisi iklim lain untuk mencapai suatu hasil yang optimal.

\section{Rekomendasi}

Fasade yang optimal dalam kenyamanan termal dirancang dengan pendekatan iklim tropis di kota Bandung dengan menerapkan metode double skin sekaligus menjadi selubung bangunan. Pada dasarnya, fasade dirancang dengan pola bukaan dengan sistem gerak engsel dengan ukuran deretan lubang bukaan $0.7 \mathrm{~m} \times 0.7 \mathrm{~m}$. double skin fasade digunakan pada bagian bangunan yang terkena kondisi outdoor termal kurang nyaman, sehingga fasade mampu menangkap kondisi outdoor menjadi optimal setelah masuk ke indoor. Dalam mengukur kenyamanan termal digunakan simulasi Sun-Hour dan pengambilan data dari Meteoblue untuk mengetahui dimana fasade seharusnya terpasang. Kenyamanan termal pada ruangan terukur menggunakan Rayman dan CBE Thermal Comfort Tool dengan hasil rata-rata kenyamanan termal indoor $21^{\circ} \mathrm{C}-25^{\circ} \mathrm{C}$. Simulasi merupakan metode pendukung yang harus diterapkan dalam setiap proses mendesain untuk mencapai hasil yang optimal dan meningkatkan tingkat keberhasilan desain sebelum terbangun. Kegiatan simulasi harus dijadikan suatu standar perencanaan dengan validasi tertentu yang sudah teruji keberhasilannya dalam proses pembangunan yang sudah ada. Simulasi dengan metode software digital akan mengindikasikan trial and error produk yang direncanakan untuk pencapaian keberhasilan desain dengan hasil yang terukur dengan pasti.

\section{Ucapan Terimakasih}

Penulis ucapak terima kasih yang mendalam kepada Dr. Eng Beta Paramitha, S.T., M.T. sebagai dosen di program studi Arsitektur FPTK UPI yang telah membimbing selama penulis mengikuti mata kuliah Arsitektur Tropis, dan semua pihak yang tidak dapat Penulis disampaikan satu persatu. 


\section{Referensi}

Ahmed, R. (2018a). Brise Soleil House. Retrieved October 4, 2018, from https://www.arch2o.com/brise-soleilhouse-studio-workshop/

Ahmed, R. (2018b). Restaurant Bossa. Retrieved October 4, 2018, from https://www.arch2o.com/restaurantbossa-rosenbaum-muti-randolph/

Anjani, H. P. (2017). 10 Tujuan Wisata Paling Populer di Indonesia Tahun 2017.

Anonymity A https://www.dezeen.com/2015/04/04/jya-rchitects-forest-house-restaurant-cheongcheon/, last accessed on August 2018.

ASHRAE. 1992. ANSI/ASHRAE Standard 55-1992, Thermal Environmental Conditions for Human Occupancy, Atlanta: American Society of Heating, Refrigerating, and Air-Conditioning Engineers, Inc.

Bangunan, T. F., Ruang, T., \& Arsitetkur, D. A. N. (2013). M.. Suparno Sastra.2013, Inspirasi Fasade Rumah Tinggal. C.V Andi Offset, Yogyakarta. 48 Hal. 3, 48-90.

Fanger PO. 1970. Thermal Comfort. Copenhagen: Danish Technical Press.

Fanger PO. and J. Toftum. 2002. Prediction of Thermal Sensation in Non-Air Conditioned Buildings in Warm Climates

Gallardo, M. Palme, A. Lobato-Cordero, R. Beltrán, and G. Gaona. 2016. Evaluating Thermal Comfort in a Naturally Conditioned Office in a Temperate Climate Zone.

Greenship untuk Gedung Baru. 2012. Ringkasan Kriteria dan Tolak Ukur. GBCI

ISO 7730. Moderate thermal environments - Determination of the PMV and PPD indices and specification of the conditions for thermal comfort.

Meteoblue. (2018). Bandung Wind Rose. Retrieved October 4, 2018, from https://www.meteoblue.com/en/weather/archive/windrose/bandung_indonesia_1650357?daterange=20 18-09-19+to+2018-09-

26\&params $=32 \% 3 \mathrm{~B} 10+\mathrm{m}+$ above + gnd $\% 3 \mathrm{~B} 31 \% 3 \mathrm{~B} 10+\mathrm{m}+$ above + gnd $\&$ polarunit=hour\&degree_resolu tion $=22.5 \&$ value_resolution $=5 \&$ windspeedunit $=$ METER_PER_SECOND

Meteoblue Bandung https://www.meteoblue.com/en/weather/forecast/modelclimate/bandung indonesia 1650357/, last accessed on August 2018.

M. G. H. M. Kapantow, Charles R. Ngangi, and Eyverson Ruauw. 2014. Tingkat Kepuasan Konsumen di Restoran Mcdonald's Manado.

M. S. Rahma, P. Wardono, and L. N. Budiarti. 2017. Pengaruh Elemen Interior Restoran Terhadap Pengalaman Nostalgia Konsumen.

Mulyadi, R. (2016). Kinerja Fasad Selubung Ganda dalam Menurunkan Konsumsi Energi untuk Pendinginan pada Bangunan Gedung, 1037-1042.

Paramita and M. D. Koerniawan. 2013. Solar Envelope Assessment in Tropical Region Building Case Study: Vertical Settlement in Bandung, Indonesia

Permana, A. Y., dan Wijaya, K. (2013). Education City As Identity of Bandung City. In International Conference on Urban Heritage and Sustainable Infrastrcture Development (UHSID) (pp. 15-19). Semarang: Architecture Departement of Diponegoro University.

Permana, A. Y., dan Wijaya, K. (2017). Spatial change transformation of educational areas in Bandung. In IOP Conference Series: Earth and Environmental Science (International Conference on Sustainable in Architecture Design Urbanism/ICSADU) (Vol. 99, p. 012029). Semarang: IOP Conference Series: Earth and Environmental Science. https://doi.org/10.1088/1755-1315/99/1/012029

Permana, A.Y., Susanti, I., dan Wijaya, K. 2017. Kajian Optimalisasi Fasad Bangunan Rumah Tinggal dalam menunjang Program Net Zero Energy Building (NZE-Bs). Jurnal Arsitektur Arcade, vol. 1 no. 1, hal 27-34

R. Kriteria, D. a N. Tolok, and D. R. Development. 2012. Greenship Rating Tools Greenship Untuk Gedung Baru.

S. Hestiningrum. 2014. Perancangan Interior Fine Dining Restaurant.

S. Hirabayashi, T. Abe, F. Imamura, and C. Morioka. 2018. Development of a distributed modeling framework to estimate thermal comfort along 2020 Tokyo Olympic marathon course. 